Discussion Paper No. 06-003

\title{
Differentiation of Green Taxes: A Political-Economy Analysis for Germany
}

Niels Anger, Christoph Böhringer and Andreas Lange

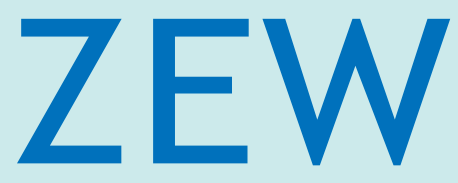

Zentrum für Europäische Wirtschaftsforschung $\mathrm{GmbH}$ Centre for European Economic Research 
Discussion Paper No. 06-003

\section{Differentiation of Green Taxes: A Political-Economy Analysis for Germany}

Niels Anger, Christoph Böhringer and Andreas Lange

Download this ZEW Discussion Paper from our ftp server:

ftp://ftp.zew.de/pub/zew-docs/dp/dp06003.pdf

Die Discussion Papers dienen einer möglichst schnellen Verbreitung von neueren Forschungsarbeiten des ZEW. Die Beiträge liegen in alleiniger Verantwortung der Autoren und stellen nicht notwendigerweise die Meinung des ZEW dar.

Discussion Papers are intended to make results of ZEW research promptly available to other economists in order to encourage discussion and suggestions for revisions. The authors are solely responsible for the contents which do not necessarily represent the opinion of the ZEW. 


\section{Nontechnical Summary}

Over the last decade, environmental (green) taxes on energy or emissions have played a growing role in environmental policies of OECD countries. As a common feature of green tax schemes, tax rates are differentiated across polluters: Taxation typically discriminates in favor of energy-intensive industries including, as an extreme case, complete tax exemptions. The lack of a stronger efficiency rationale for such a policy design provides the motivation for our political-economy analysis, which assesses the role of interest groups in environmental tax differentiation both theoretically and empirically.

Using a common-agency model, we provide predictions on tax differentiation which are then tested using data from the German Ecological Tax Initiative. As the reform is revenue neutral and reduces labor costs, in our model tax differentiation is not only determined by the activity of lobby groups favoring reduced tax rates, but also by the groups' interest in revenue rebates to labor. We demonstrate that sectors with good opportunities to substitute energy use will ceteris paribus be expected to face higher taxes in a political-economy setting, and have lower incentives to lobby for tax reductions. Benefits from lobbying are largest for sectors with highly inelastic energy use: On efficiency grounds, such sectors would be assigned high taxes as they are less distortionary than in other sectors. The resulting high costs from taxation, however, lead to high lobbying incentives which in turn can translate into substantially reduced taxes.

A regression analysis of Germany’s green tax reform shows that environmental tax differentiation is consistent with political-economy reasoning. Underpinning our theoretical predictions, both economic characteristics of industries and political interests determine the design of the tax scheme. The reform clearly discriminated in favor of industries represented by more powerful lobbies, in particular those with highly inelastic emissions use. The success in lobbying depends, e.g., on market concentration, the level of international competition, and employment levels. However, in general these issues only become relevant when lobby groups put them on the political agenda as arguments against environmental taxation. This complements the findings from the literature that tax differentiation can hardly be justified on efficiency grounds: Only in a political-economy context, the potential arguments in favor of differentiation become effective. 


\title{
Differentiation of Green Taxes:
}

\section{A Political-Economy Analysis for Germany}

\author{
Niels Anger ${ }^{\mathrm{a}}$, Christoph Böhringer ${ }^{\mathrm{a}, \mathrm{b}}$ and Andreas Lange
}

\begin{abstract}
In this paper we study political-economy determinants of the differentiation of environmental taxes between sectors. Using a common-agency model, we provide predictions on tax differentiation which are then tested using data from the German Ecological Tax Reform. As the reform is revenue neutral and reduces labor costs, tax differentiation is not only determined by the activity of lobby groups favoring reduced tax rates, but also by the groups' interest in revenue rebates to labor. Empirical data underpin our theoretical findings: A regression analysis of Germany’s green tax reform explains environmental tax differentiation by the presence of sectoral interest groups. Besides market concentration and energy demand elasticities, the exposure of industries to international trade flows plays an important role in the environmental tax design.
\end{abstract}

JEL classification: D62, H23, P16

Keywords: environmental tax reform, interest groups, common agency

Acknowledgements: The authors are grateful to Stefan Bach and the German Institute of Economic Research for providing us with data on the German Ecological Tax Reform. We also thank Heinz Welsch for international trade data, Eric Naevdal for valuable comments and Sabine Jokisch for helpful data support.

\footnotetext{
${ }^{\mathrm{a} C e n t r e ~ f o r ~ E u r o p e a n ~ E c o n o m i c ~ R e s e a r c h ~(Z E W), ~ M a n n h e i m, ~ G e r m a n y ~}$

${ }^{\mathrm{b}}$ University of Heidelberg, Center for Environmental Economics, Germany

${ }^{\mathrm{c}}$ University of Maryland, Department of Agricultural and Resource Economics, USA
}

Correspondence: Niels Anger, Centre for European Economic Research (ZEW), P.O. Box 1034 43, 68034 Mannheim, Germany; e-mails: anger@zew.de; boehringer@zew.de; alange@arec.umd.edu 


\section{Introduction}

Over the last decade, environmental (green) taxes on energy or emissions have played a growing role in environmental policies of OECD countries. As a common feature of green tax schemes, tax rates are differentiated across polluters: Taxation typically discriminates in favor of energy-intensive industries including, as an extreme case, complete tax exemptions (OECD 2001).

While textbook economics suggests uniform taxes to internalize environmental externalities, market imperfections or distortions are potential reasons why sectorally differentiated taxes might be desirable under efficiency considerations. Environmental tax differentiation may for example attenuate the inefficiencies of existing (fiscal) taxes and labor market rigidities (see, e.g., Richter and Schneider 2003) and alleviate the negative effects from leakage, i.e. increased transboundary pollution from non-abating countries (Hoel 1996). Accounting for market power of large open economies, differentiated environmental taxes may also be enacted to change terms-of-trade against trading partners ("beggar-thy-neighbor” policy - see, e.g., Krutilla 1991, Anderson 1992, Rauscher 1994).

Surprisingly, quantitative evidence to back these theoretical arguments is rather scant. Drawing on simulations with a computable general equilibrium model based on empirical data, Böhringer and Rutherford (2002) conclude "that there is little economic rationale for the common policy practice of discriminating strongly in favor of heavy industries, even when accounting for interacting taxes, leakage, and international market power.“ Indeed, Babiker et al. (2000) and Kallbekken (2004) identify large welfare costs from differentiating climate policy by sector: studying realistic differentiation scenarios, they find that costs of reaching a certain emission target can easily double compared to an efficient implementation.

The lack of a stronger efficiency rationale provides the motivation for our analysis. This paper assesses the role of interest groups in environmental tax differentiation both theoretically and empirically.

Positive theories on the role of interest groups in policy formation use various alternative models to study political determinants of environmental policy. ${ }^{1}$ Our theoretical approach uses a common-agency problem in the tradition of Grossman and Helpman (1994): Interest groups can influence decisions of policy makers by means of donations to election campaigns. While political-economy determinants of environmental tax design have been studied before (see Frederiksson 1997 and Aidt 1997, 1998 on the role of international competition on the tax level and the role of tax rebates in a revenue-neutral tax reform), we provide, to our knowledge, the first combined theoretical and empirical analysis on political-economy effects on tax differentiation.

We demonstrate that sectors with good opportunities to substitute energy use will (i) ceteris paribus be expected to face a higher tax in a political-economy setting, and (ii) have lower incentives to lobby for tax reductions. Benefits from lobbying is largest for sectors with highly inelastic energy use: While it is efficient to assign high

\footnotetext{
${ }^{1}$ An overview is given by Oates and Portney (2003). Rent-seeking models describe how interest groups compete for group-specific rents (Tullock 1980), specifically in the context of environmental instrument choice (Dijkstra 1998). In Probabilistic-voting models lobby groups exert influence on the policy maker through the potential, yet uncertain votes of their members (Coughlin 1992). Models of information transfer are based on exchange of true information between interest groups and policy maker, on which the politician bases her decisions (Grossman and Helpman 2001, Naedval and Brazee 2000, Potters and van Winden 1992).
} 
taxes on inelastic factors, the resulting high costs from taxation induce large lobbying incentives and are predicted to lead to substantially reduced tax levels for sectors with inelastic energy use.

Our results from an empirical analysis of the German Ecological Tax Reform are consistent with these predictions. The reform clearly discriminated in favor of industries represented by more powerful lobbies, in particular those with highly inelastic emissions use. The effect of lobbying on the resulting tax rates depends on energy demand elasticities, employment levels or the level of international competition. This result complements the findings from the literature mentioned above that tax differentiation can hardly be justified on efficiency grounds: Only in a political-economy context, the potential arguments in favor of differentiation become effective.

The remainder of this paper is organized as follows. In section 2, we describe a common-agency model to derive differentiated environmental taxes under political-economy considerations. In section 3, we present a regression analysis for green taxation in Germany, which to our knowledge provides a first quantitative assessment of the role of interest groups in environmental tax differentiation. In section 4, we conclude.

\section{$2 \quad$ A political-economy model of differentiated green taxes}

We study a common-agency model of a small open economy to analyze political-economy motivations to differentiate environmental taxes. The model is in the tradition of Aidt (1998) and Grossman and Helpman (1994). The desire of some sectors to avoid costs due to taxation affects the policy choice of a government (regulator) which is not only interested in overall welfare but also values contributions (support) by the different interest groups.

We consider an economy with $s=1, \ldots, n$ sectors and a representative consumer who earns all the labor income and holds all the profit shares of the firms. In the production sectors, competitive firms produce output by using labor $l_{s}$, energy (emissions) $e_{s}$ and some other inputs (capital) which we do not explicitly model here. Output $q_{s}$ of sector $s$ is produced via a concave production function $f^{s}\left(e_{s}, l_{s}\right)$ and can be sold at world market $p_{s}{ }^{2}$ To simplify the exposition of our results, we assume that the production decisions on labor and energy are separable, i.e. $\partial^{2} f^{s} / \partial e \partial l\left(e_{s}, l_{s}\right)=0$. Further, energy has to be imported from the world market at unit costs $\bar{Z}$.

The German ecological tax reform lifted burdens on labor by taxing energy use. Reflecting this feature, we assume that the regulator taxes emissions (energy use) at a rate $\tau_{s}$ such that firms face unit costs of energy (emissions) $Z_{s}=\bar{Z}+\tau_{s}$. For the wage rate which is identical for all sectors, we follow Bovenberg and Ploeg

\footnotetext{
${ }^{2}$ With this formulation, we implicitely assume a competitive world market such that we do not have to consider consumption choices and consumer surplus in the domestic market. More generally, a sector could face a downward sloping demand if no (perfect) substitutes are produced by producers abroad. We will discuss the effects of such a generalization at a later stage in this paper.
} 
(1996) in assuming that labor supply is rationed by an exogenous employees wage $\bar{w}_{e}$. Energy taxes are used to reduce the tax wedge between employee and producer wage $\bar{w}_{p}$ The effective producer wage is therefore given by $w=\bar{w}_{p}-\sigma$ where $\sigma$ will be endogenously determined by the tax yield.

In modeling the ecological tax reform, we assume that the regulator taxes emissions in order to achieve an aggregate target of

$$
\bar{E}=\sum_{s} e_{s}
$$

As the tax reform is revenue-neutral, the tax yield will be used to reduce the social security taxes on labor such that the reduction of social security burdens $\sigma$ is determined by.

$$
\sigma \sum_{s} l_{s}=\sum_{s} \tau_{s} e_{s}
$$

Note that with this setting, profits of the respective sectors are given by

$$
\pi_{s}=p_{s} f^{s}\left(e_{s}, l_{s}\right)-\left(\bar{z}+\tau_{s}\right) e_{s}-\left(\bar{w}_{p}-\sigma\right) l_{s} .
$$

Social welfare is given by: ${ }^{3}$

$$
W=\bar{w}_{e} \sum_{s} l_{s}+\sum_{s} \pi_{s}+\psi\left[\sum_{s} \tau_{s} e_{s}+\left(\bar{w}_{p}-\bar{w}_{e}-\sigma\right) l_{s}\right]
$$

where $\psi \geq 1$ denotes the marginal costs of public revenue.

Depending on the policy chosen by the government, the production decisions by competitive profit-maximizing firms are given by the following well-known first-order conditions:

$$
p_{s} f_{e}^{s}\left(e_{s}, l_{s}\right)=\bar{z}+\tau_{s} \quad p_{s} f_{l}^{s}\left(e_{s}, l_{s}\right)=\bar{w}_{p}-\sigma
$$

which leads to

$$
\frac{d \pi_{s}}{d \tau_{s}}=-e_{s} \quad \frac{d \pi_{s}}{d \sigma}=l_{s}
$$

\section{$2.1 \quad$ Political interests}

The government chooses the tax/rebate system $\left(\tau_{s}, \sigma\right)$ in order to implement its environmental goal $\bar{E}=\sum_{s} e_{s}$. Hereby, the rebate is implicitly determined by the tax system and guarantees revenue-neutrality: $\sigma \sum_{s} l_{s}=\sum_{s} \tau_{s} e_{s}$. In designing the policy, the government does not only care about social welfare but additionally takes contributions $T_{s}\left(\left(\tau_{t}\right)_{t}\right)$ (support) by sectoral lobby groups into account. We assume that there is a lobby group for each sector $s$. The value which the government attaches to contributions from lobby groups 
might differ across sectors, i.e. interest groups might differ with respect to their effectiveness in lobbying. The weight which contributions by the lobby groups of the respective sectors receive is denoted by $\lambda_{s}$.

Taking the support by the respective lobby groups into account, the objective of the government is to maximize

$$
G\left(\left(\tau_{t}\right)_{t}\right)=W\left(\left(\tau_{t}\right)_{t}\right)+\sum_{s} \lambda_{s} T_{s}\left(\left(\tau_{t}\right)_{t}\right)
$$

Before the government decides upon the tax rates, each lobby group offers a menu of campaign contributions depending on the chosen policy $T_{s}\left(\left(\tau_{t}\right)_{t}\right)$ in order to optimally influence the profits in its sector (Bernheim and Whinston 1986). In our analysis we concentrate on the equilibrium which is given by each lobby group (locally) truthfully reporting their costs and benefits form the respective policy (existence shown, e.g., in Grossman and Helpman 1994, Aidt 1998). Each contribution schedule $T_{s}\left(\left(\tau_{t}\right)_{t}\right)$ is hence given by the sectoral profits $\pi_{s}$ less a constant.

The optimization problem (7) of the government therefore is to maximize

$$
G\left(\left(\tau_{t}\right)_{t}\right)=W\left(\left(\tau_{t}\right)_{t}\right)+\sum_{s} \lambda_{s} \pi_{s}\left(\left(\tau_{t}\right)_{t}\right)
$$

by choosing $\left(\tau_{t}\right)_{t}$ and $\sigma$ subject to (1) and (2). ${ }^{4}$

Using the firms’ first-order conditions (5) and (6) and denoting the Lagrange multipliers for (1) and (2) by $\mu_{1}$ and $\mu_{2}$, we obtain the following first-order conditions:

$$
0=\frac{\partial G}{\partial \sigma}=\sum_{s}\left(\lambda_{s}+1\right) l_{s}+\bar{w}_{e} \frac{\partial L}{\partial \sigma}+\psi\left(\bar{w}_{p}-\bar{w}_{e}\right) \frac{\partial L}{\partial \sigma}-\left(\psi+\mu_{2}\right)\left[\sigma \frac{\partial L}{\partial \sigma}+L\right]
$$

and

$$
0=\frac{\partial G}{\partial \tau_{s}}=-\left(\lambda_{s}+1\right) e_{s}-\mu_{1} \frac{\partial e_{s}}{\partial \tau_{s}}+\left(\psi+\mu_{2}\right)\left[\tau_{s} \frac{\partial e_{s}}{\partial \tau_{s}}+e_{s}\right]
$$

where $L=\sum_{s} l_{s}$ and $E=\sum_{s} e_{s}$.

Conditions (9) and (10) determine the optimal differentiation of taxes and can be rewritten as:

$$
\mu_{2}+\psi-1=\sum_{s} \lambda_{s} l_{s} / L+\left[\bar{w}_{e}+\psi\left(\bar{w}_{p}-\bar{w}_{e}\right)-\left(\psi+\mu_{2}\right) \sigma\right] \frac{\partial L}{\partial \sigma} / L
$$

3 As we assume that the aggregate emission target $\bar{E}$ is fixed in our analysis, we can disregard the environmental impact of emissions which, clearly, are the motivation to pursue the reform in the first place.

${ }^{4}$ Equivalently to modeling contributions by the lobby groups, this objective function resembles the welfare in which different sectors receive different weights. This can be due to different political connections between government and sectors. In Germany, for example, much of the labor force in the coal industry was organized in labor unions which traditionally had strong linkages to the Social Democrats which lead the government when the ecological tax reform was introduced. 


$$
\tau_{s}=\frac{\mu_{1}}{\psi+\mu_{2}}-\frac{\psi+\mu_{2}-1-\lambda_{s}}{\psi+\mu_{2}} \frac{e_{s}}{\partial e_{s} / \partial \tau_{s}}
$$

We use these two conditions to discuss the impact of lobbying on the differentiation of taxes.

\subsection{The impact of interest groups}

First observe that if there is no political power of interest groups, $\lambda_{s}=0$ for all $s$, then

$$
\begin{gathered}
\mu_{2}+\psi-1=\left[\bar{w}_{e}+\psi\left(\bar{w}_{p}-\bar{w}_{e}\right)-\left(\psi+\mu_{2}\right) \sigma\right] \frac{\partial L}{\partial \sigma} / L \\
\tau_{s}=\frac{\mu_{1}}{\psi+\mu_{2}}-\frac{\psi+\mu_{2}-1}{\psi+\mu_{2}} \frac{e_{s}}{\partial e_{s} / \partial \tau_{s}}
\end{gathered}
$$

In this case, condition (12') implies that taxes will be differentiated because of a "tax yield" effect. This effect, $-\frac{\psi+\mu_{2}-1}{\psi+\mu_{2}} \frac{e_{s}}{\partial e_{s} / \partial \tau_{s}}$, causes taxes to be higher in sectors with relatively inelastic emissions. This term thereby corresponds to a standard Ramsey-formula. Only if tax generation does not cause social costs $(\psi=1)$ and the revenue neutrality constraint is not binding ( $\mu_{2}=0$ ), no differentiation due to tax generation results.

Lobby activities by a sector $s$ are targeted at reducing the net payments of taxes, $\tau_{s} e_{s}-\sigma l_{s}$. It is clear, that ceteris paribus - energy-intensive sectors face higher effective costs than labor-intensive sectors. Although conditions (11') and (12') show that differences in energy and labor intensities across sectors alone do not induce differentiated taxes, we can decompose the net tax payments in energy taxes and rebates on labor to discuss the impact of lobbying via two different channels: First, the sectoral lobby group wants to reduce its own tax rate $\tau_{s}$. Second, as there will be a rebate according to the labor input in the sector, lobbies are interested in a higher rebate $\sigma l_{s}$ which can only be obtained by an increase in aggregate tax revenues. Both effects can be seen from equation (11) and (12) as we will show in turn.

The first channel can be seen from partially differentiating the tax rate $\tau_{s}$ with respect to $\lambda_{s}$ which gives a negative derivative: $\partial \tau_{s} / \partial \lambda_{s}=\frac{1}{\psi+\mu_{2}} \frac{e_{s}}{\partial e_{s} / \partial \tau_{s}}<0$. Consequently, even if there is no restriction on the revenue-neutrality $\left(\mu_{2}=0\right.$ ) and $\psi=1$, differentiated taxes will result because of lobby activities. More effective lobbying results in a reduced tax rate. This effect of lobbying on the tax rate is the more pronounced, the less elastic emissions in the sector are, i.e., the less substitutable energy use is (condition (12)). Intuitively, 
given equal lobby power $\lambda_{s}$, sectors which can hardly abate emissions by shifting production patterns will end up with a smaller emissions tax than sectors which can reduce emissions and thereby tax payments rather easily. The second channel is created by linking the ecological tax with rebates on labor use. Adding to the complexity of lobbying activities, firms with interest in large rebates must lobby for a larger total tax yield. ${ }^{5}$ This interest in increasing the total tax yield is represented by the positive derivative of $\mu_{2}$ with respect to $\lambda_{s}$ : $\partial \mu_{2} / \partial \lambda_{s}=l_{s} /\left[L+\frac{\partial L}{\partial \sigma} / \sigma\right]>0$. The effect a sector has in lobbying for the higher tax yield is the larger, the larger the labor use in this sector is and, hence, the larger the expected rebate of the tax yield is. The resulting effect on the tax rate can be seen from (12): Here we obtain $\partial \tau_{s} / \partial \mu_{2}=-\frac{1}{\partial e_{s} / \partial \tau_{s}} \frac{\tau_{s} \frac{\partial e_{s}}{\partial \tau_{s}}+e_{s}}{1+\mu_{2}}$ which is positive if and only if an increase in the tax rate $\tau_{s}$ increases the aggregate tax yield.

\subsection{Explaining the lobby weight of interest groups}

The lobby weight of the respective interest groups can clearly not directly be observed in the real world. Olson (1965) develops a theory to explain the formation and the power of interest groups. In particular the group size matters: If the number of firms in a sector is large, a smaller degree of organization can be expected unless this sector is dominated by only a smaller number of big firms, i.e., the level of concentration is large. These general characteristics of a sector can be expected to determine lobby activities of these sectors in all policy fields and thus can be used as proxy in the empirical analysis.

In addition to these general determinants, the formation of interest groups is affected by the stakes which are on the table. For the policy field of an ecological tax reform, our model therefore yields specific predictions on the lobby weights as stakes differ substantially across sectors: In general, all sectors are interested in an increase in the rebate on labor and shift of the tax burden from them to other sectors. In particular sectors with a large labor force favor an increasing aggregate tax yield without being burdened themselves. However, as taxes and tax yield are interdependent, predictions depend on the impact of sectoral tax rates on the tax yield.

We first consider sectors with highly inelastic emissions. From condition (12) we see that if such sectors lack lobby power $\left(\lambda_{s}<\psi+\mu_{2}-1\right)$, they will be burdened with a huge emissions tax as taxing them in order to generate tax yield is less distortionary than taxing sectors with elastic demand. If, however, such a sector with inelastic emission use is highly effective in lobbying $\left(\lambda_{s}>\psi+\mu_{2}-1\right)$ it will face only a small emissions tax since otherwise its tax burden would be huge as it cannot reduce it by shifting production patterns. The incentives to lobby for sectors with inelastic emissions use are therefore large, in particular if they are highly

\footnotetext{
${ }^{5}$ In a more general model, one clearly could introduce differentiated rebate rates for the sectors. In such a case, lobbies could directly target their specific rebate. In order to be close to the German tax reform , however, we do not consider this additional policy instrument variable.
} 
energy-intensive. ${ }^{6}$ We can therefore expect such sectors to form a lobby group to avoid taxes. These sectors might only support an ecological tax reform if they are granted large exemptions and are labor-intensive and would therefore benefit from tax rebates.

Lobbying activities by sectors with highly elastic emissions use, however, have only a small effect on the resulting tax rate (condition (12)). The reason is that they can easily reduce tax payments by changing their production activities. These sectors have therefore only small incentives to lobby for tax reductions. They can be expected to support the ecological tax reform the more, the larger their labor force is, i.e., the larger their expected benefit from reducing social security payments on labor.

\section{$2.4 \quad$ The role of international competition}

In our model we have assumed that all sectors face an exogenously given output price at which firms can sell their products. In general, however, firms face international competition to different degrees. As foreign competitors are not subject to taxation, the competitiveness of domestic firms is decreased by the environmental taxes which, at the margin, might lead to firm-closures and relocation. Considering these potential effects on firms and workforce, the regulator might want to discriminate taxes in favor of those sectors which face strong international competition.

\subsection{Summary of theoretical predictions}

Using our simple theoretical model, we can summarize predictions on the role of lobbying on environmental taxes: ${ }^{7}$

- Without lobbying, emission taxes are differentiated if (i) they replace distortionary taxes (marginal costs of social funds $>1$ ), (ii) sectors face different degrees of international competition or (iii) sectors feature different degrees of emissions elasticity.

- Lobbying leads to a differentiation of environmental taxes. Increased lobbying in a sector leads to reduced taxes.

- Lobbying is most beneficial for sectors with inelastic emissions such that we should expect the formation of lobby groups as well as reduced tax rates particularly in those sectors.

- Labor intensive sectors which get a substantial rebate will benefit from the tax reform.

In the next section, we put these predictions to a test using a regression analysis of the German Ecological Tax Initiative.

\footnotetext{
${ }^{6}$ The cement industry provides a frequently cited example for an energy-intensive sector with few possibilities to substitute. Here, stakes are accordingly substantial.

${ }^{7}$ It should be noted that in our model we assume that the ecological target of the tax reform is fixed. That is, a lower burden for one sector results in increased burdens for others. In reality, however, the regulator can quite often compromise on the ecological goal in order to increase the approval for the policy instrument as such. The emission level which results in such a setting, could then be taken as input in our model.
} 


\section{Regression analysis of the German Ecological Tax Reform}

Between 1999 and 2003 Germany implemented a green tax reform with the goal of obtaining a "double dividend”, i.e. reducing energy-related emissions and increasing employment. The reform levied higher taxes on energy use while recycling the additional energy tax yield through a reduction of employer's social security contributions. A central feature of Germany's green tax reform, which can be generalized to green tax reforms in other OECD countries (OECD 2001), are substantial energy tax breaks for energy-intensive firms (Böhringer and Schwager 2003). In our regression analysis, we aim at identifying central determinants of German green taxation. The estimations will provide an empirical assessment of the theoretical role of interest groups in environmental tax differentiation as laid out in section 2.

\subsection{Data and variables}

The cross-sectional regression analysis covers all 42 manufacturing sectors of the German economy as provided by the official input-output classification (see Table 1 of the Appendix for a list of sectors). The basis of our empirical analysis is a sector level data set for Germany, which was compiled from various sources. ${ }^{8}$ We collected data on lobby representatives of German industrial associations by a telephone survey of the respective organizations. For statistical consistency, we made a couple of choices regarding the relevant years of observation: Energy use, taken from 1998, served as a base for the design of the reform which was determined by the German government in 1999. Net burdens as well as energy tax rates in the year 2003 represent the final tax levels after a yearly, stepwise increase since 1999, the year in which they were politically determined. Employees of German industrial associations in 1995 reflect the fact that the political debate about the Ecological Tax Initiative reached its climax already in the mid-1990s. For the same reason, price elasticities of energy use as well as production and employment as important issues of the political debate are taken from this period, and estimates of politically relevant Armington elasticities are based on time-series data ending in 1990. Due to data availability, market concentration is observed in 2001. Consequently, the chosen time lag between the years of observation of tax rates and major explanatory variables assures that a potential problem of endogeneity (environmental taxation may have an effect on independent variables, e.g., on energy use) is attenuated.

As dependent variables we employ the three tax components of the reform: the average effective tax rates for electricity, gas and fuel oil (i.e., rates including reductions), as well as the net burden (the overall tax reform burden). These are structural variables reflecting the sectorally differentiated character of the tax initiative. As in our theoretical analysis, we will generally focus on the tax rate which was central to the actual political debate. The explanatory variables reflect political-economy determinants of environmental tax differentiation: lobbying power, market concentration and the exposure to international competition. We furthermore control for central

\footnotetext{
${ }^{8}$ Data on sectoral energy use, tax rates and net burdens was provided by the German Institute of Economic Research (see Bach et al. 2003, 2001). Sectoral production and employment data are taken from offical inputoutput tables, and data on sector-specific price elasticities of energy demand is based on Capros et al. (1999). Market concentration data stems from the German Monopolies Commission (German Monopolies Commission 2004a, 2004b). Estimates of Armington elasticities are taken from an econometric analysis by Welsch (2004).
} 
objectives and implementation features of the green tax reform by introducing the following regressors: energy intensities (energy use per production value), sectoral employment levels, and price elasticities of fuel demand (an overview of all regression variables is provided in Table 2 of the Appendix; summary statistics for the variables are given in Table 3 of the Appendix). Finally, we incorporate various interaction terms in order to infer how the effect of one explanatory variable depends on the magnitude of other explanatory variables.

As a measure for lobbying power or effectiveness we employ the number of lobby employees for the representative industrial association in each sector (see Table 4 of the Appendix for a mapping between sectors and respective associations): According to the theory of interest groups, the transfer of information between groups and policy makers is understood as an important channel of political influence by lobby groups. ${ }^{9}$ Communication as one means to express group interests should be the more effective, the more representatives a lobby employs. With respect to market concentration, the average sectoral Herfindahl-Hirschman Index (HHI) is employed as a standard measure. ${ }^{10}$ To represent international trade issues we use Armington elasticities of substitution between imports and competing domestic goods. Intensities for electricity, gas, fuel oil, and total energy are employed as independent variable because a central design feature of Germany's green tax reform has been to relieve the burden on energy-intensive sectors by granting generous tax breaks. Here, we use logarithmized variables in order to reflect that the tax rate reductions for firms are granted already from rather low levels of energy use onwards, i.e., differences in tax burdens between sectors with lower energy-intensity should be stronger than between energy-intensive industries. ${ }^{11}$ The incorporation of the sectoral employment level as an independent variable allows us to investigate the burdens induced on sectors with a large working force, as German industries generally opposed the reform by threatening with potential layoffs and the recycling of the energy tax revenues leads to a reduction in labor costs. Price elasticities of fuel demand (distinguished by fuel types) are introduced in order to test predictions of our theoretical model, where energy demand elasticities played a crucial role for the environmental tax design.

In our regression analysis on the determinants of green tax differentiation, we start from a central model specification which we extend subsequently to cover additional political-economy aspects. Thereby, the isolated effects of distinct determinants in each specification can be analyzed. We employ the standard multiple linear regression model, where, for each regression specification, $Y_{s}$ denotes the dependent variable with $S$ sectoral observations, $X_{i s}$ refer to the independent variables with associated coefficients $\beta_{i}$, and $e_{\mathrm{s}}$ is a disturbance term:

$$
Y_{s}=\beta_{0}+\beta_{1} X_{1 s}+\beta_{2} X_{2 s}+\ldots+\beta_{n} X_{n s}+e_{s}
$$

\footnotetext{
9 See Grossman and Helpman (2001), Naedval and Brazee (2000) and Potters and van Winden (1992)

${ }^{10}$ In general the $\mathrm{HHI}$ is calculated by squaring the market share of each firm competing in the respective market/sector and summing up the resulting numbers.

${ }^{11}$ The discrete negative relationship between energy intensity and the tax rate at the firm level can be transferred to a continuous logarithmic relationship at the sectoral level, where energy intensities and tax rates of individual firms are aggregated.
} 
Coefficients are estimated by ordinary least squares (OLS) with robust standard errors and have been standardized (so-called Beta coefficients).

\subsection{Basic determinants of taxation and the role of lobbying}

In the specification of our basic regression model, the average effective tax rates on electricity, gas, and fuel oil as well as the sector's net burden are explained at the sectoral level by four independent variables: ${ }^{12}$ energy intensities, employment level, price elasticities of energy demand and lobbying power. Table 5 shows the estimation results for coefficients of the basic regression specification (specification 1), as well as the goodness of fit for each equation. ${ }^{13}$

Table 5: Parameter estimation of the basic regression specification (specification 1)

\begin{tabular}{|c|c|c|c|c|}
\hline Explanatory & $E L E \_T A X$ & GAS_TAX & $O I L \_T A X$ & NETB \\
\hline $\log E L E \_I N T$ & $\begin{array}{c}-0.534 * * * \\
(-2.96)\end{array}$ & & & \\
\hline logGAS_INT & & $\begin{array}{c}-0.47 * * * \\
(-2.90)\end{array}$ & & \\
\hline logOIL_INT & & & $\begin{array}{c}0.255 * \\
\text { (1.73) }\end{array}$ & \\
\hline $\log E N \_I N T$ & & & & $\begin{array}{l}0.118 \\
(1.44)\end{array}$ \\
\hline EMPL & $\begin{array}{c}0.277 * \\
(1.77) \\
\end{array}$ & $\begin{array}{l}0.249 \\
(1.44)\end{array}$ & $\begin{array}{c}0.500 * * * \\
(2.90)\end{array}$ & $\begin{array}{c}-0.834 * * * \\
(-7.31)\end{array}$ \\
\hline$E \_E L E$ & $\begin{array}{l}-0.073 \\
(-0.78)\end{array}$ & & & \\
\hline E_GAS & & $\begin{array}{l}-0.002 \\
(-0.02)\end{array}$ & & \\
\hline E_OIL & & & $\begin{array}{c}-0.239 * \\
(-1.97)\end{array}$ & \\
\hline E_FUEL & & & & $\begin{array}{l}0.032 \\
(0.35)\end{array}$ \\
\hline LOBBY & $\begin{array}{l}-0.180 \\
(-1.63)\end{array}$ & $\begin{array}{c}-0.256 * * \\
(-2.26)\end{array}$ & $\begin{array}{c}-0.367 * * * \\
(-2.92)\end{array}$ & $\begin{array}{l}0.032 \\
(0.16)\end{array}$ \\
\hline Constant & $\begin{array}{c}3.400 * \\
(1.92)\end{array}$ & $\begin{array}{c}0.451 * * * \\
(2.74)\end{array}$ & $\begin{array}{c}9.220 * * * \\
(4.96)\end{array}$ & $\begin{array}{l}9.891 \\
(0.36)\end{array}$ \\
\hline Goodness of fit & $\mathrm{R}^{2}=0.53$ & $\mathrm{R}^{2}=0.37$ & $\mathrm{R}^{2}=0.29$ & $\mathrm{R}^{2}=0.78$ \\
\hline
\end{tabular}

Z-statistics in parentheses. ${ }^{*}(* *, * * *)$ means the null hypothesis that the respective parameter is zero can be rejected at the $10 \%(5 \%, 1 \%)$ level of significance (according to the corresponding two-tailed test).

${ }^{12}$ The net burden is defined as the difference between overall tax payments and reimbursements in terms reduced social security contributions by employers.

${ }^{13}$ In the table, each column represents one regression equation, non-empty cells showing coefficients of the respective explanatory variables. 
We observe highly significant negative coefficients of the logarithmized electricity and gas intensity in the respective tax rate regressions: According to our data set, the more energy-intensive sectors face a lower effective electricity and gas tax rate. The logarithmic specification implies that in absolute terms this effect is weaker for higher intensities, i.e., differences in effective tax rates between sectors with lower energy-intensity are larger than those between energy-intensive sectors. The green tax reform thus discriminates in favor of energy-intensive sectors - a result that is consistent with the tax break regulations at the firm level. ${ }^{14}$

The effects of the employment level on tax rates for electricity and oil are (weakly and highly) significant and positive: Our data suggest that sectors with a larger working force bear higher energy tax rates. At first glance, this result seems contradictory to the stated labor market goals of Germany's green tax reform. However, if we additionally account for the net burden induced by the reform as a dependent variable, we find the expected highly significant negative effect of employment on the net reform burden. Labor-intensive sectors thus in total benefit from the reform, i.e. the reimbursements of the energy tax yield more than compensate their energy tax payments.

The price elasticity of oil demand has a significantly negative impact on the oil tax rate. This result provides (weak) empirical evidence for our theoretical prediction that - ceteris paribus - sectors with inelastic energy demand will be burdened with a high energy tax rate. The coefficients of the oil and gas demand elasticities, however, are not significant.

As a central result, we find a significantly negative impact of the number of lobby employees on the tax rate for gas and oil. We conclude that industries represented by stronger associations - in terms of political communication - are able to lobby for lower energy tax rates. This finding is not only in line with Grossman and Helpman (2001) and Potters and van Winden (1992), but underpins our theoretical analysis of section 2, where we found that more effective lobbying results in a reduced tax rate and that differentiated taxes are driven by lobby activities. ${ }^{15}$

\section{3 interaction between energy demand elasticities and lobbying}

The theoretical analysis of section 2 indicates that the effects of lobbying should be more pronounced in sectors with inelastic energy use, as they would be burdened with a high energy tax when lacking lobby power and the benefits of reduced tax rates are relatively high. We can investigate the theoretical assertion by introducing an interaction term as the ratio between the number of lobby representatives and the price elasticity of fuel demand. As we simply add the interaction term to our basic regression specification 1 , the coefficient of the variable $L O B B Y$ becomes insignificant in the gas tax and less significant in the oil tax regression. ${ }^{16}$ However, these results may emerge due to technical reasons: We observe a strong correlation between the explanatory variable $L O B B Y$ and the respective interaction terms (see Table 6), especially for electricity and oil demand elasticities.

\footnotetext{
14 The positive coefficient of the logarithmized oil intensity is not discussed here, since its weak level of significance is low compared to the negative electricity and gas intensity coefficients.

${ }^{15}$ Again note that a potential endogeneity problem of lobby formation should be reduced by our choice of years - lobby employees (1995) and tax rates (1999).

${ }^{16}$ The whole set of econometric estimations as well as the dataset can be obtained on request from the authors.
} 
As a consequence, we observe a problem of multicollinearity which - via larger standard errors - may explain the mentioned insignificant coefficient estimates.

Table 6: Correlation coefficients between $L O B B Y$ and respective interaction terms

\begin{tabular}{|c|c|c|c|}
\hline & LOBBY_EELE & LOBBY_EGAS & LOBBY_EOIL \\
\hline LOBBY & 0.966 & -0.367 & 0.727 \\
\hline
\end{tabular}

The multicollinearity problem can be addressed by dropping one of the intercorrelated variables. Since we are interested in the joint effect of $L O B B Y$ and energy demand elasticities on the respective tax rates, we drop the variable $L O B B Y$, yielding specification 2. Estimation results are presented in Table 7.

Table 7: Parameter estimation of the extended regression specification including interaction term between lobby power and energy demand elasticity (specification 2)

\begin{tabular}{|c|c|c|c|}
\hline Explanatory & $E L E \_T A X$ & GAS_TAX & OIL_TAX \\
\hline $\operatorname{logELE\_ INT}$ & $\begin{array}{c}-0.535 * * * \\
(-3.02)\end{array}$ & & \\
\hline $\log G A S \_I N T$ & & $\begin{array}{c}-0.478 * * * \\
(-2.75)\end{array}$ & \\
\hline logOIL_INT & & & $\begin{array}{c}0.237 * \\
(1.85)\end{array}$ \\
\hline EMPL & $\begin{array}{c}0.278 * \\
(1.81)\end{array}$ & $\begin{array}{l}0.161 \\
(0.95)\end{array}$ & $\begin{array}{c}0.403 * * * \\
(2.76)\end{array}$ \\
\hline$E \_E L E$ & $\begin{array}{l}-0.099 \\
(-1.05)\end{array}$ & & \\
\hline E_GAS & & $\begin{array}{l}0.011 \\
(0.10) \\
\end{array}$ & \\
\hline E_OIL & & & $\begin{array}{c}-0.463 * * * \\
(-3.63)\end{array}$ \\
\hline LOBBY_EELE & $\begin{array}{c}-0.190 * \\
(-1.69)\end{array}$ & & \\
\hline LOBBY_EGAS & & $\begin{array}{l}0.084 \\
(0.85)\end{array}$ & \\
\hline LOBBY_EOIL & & & $\begin{array}{c}-0.489 * * * \\
(-4.60)\end{array}$ \\
\hline Constant & $\begin{array}{c}3.661 * * \\
(2.05)\end{array}$ & $\begin{array}{c}0.371 * * \\
(2.34)\end{array}$ & $\begin{array}{c}12.385 * * * \\
(6.21)\end{array}$ \\
\hline Goodness of fit & 0.53 & 0.32 & 0.34 \\
\hline
\end{tabular}

Z-statistics in parentheses. * (**, ***) means the null hypothesis that the respective parameter is zero can be rejected at the $10 \%(5 \%, 1 \%)$ level of significance (according to the corresponding two-tailed test).

The coefficient estimates underline our previous results with respect to energy intensities, employment and fuel demand elasticities on the tax rate. Moreover, we find support for our theoretical findings regarding the lobbying effects for sectors with highly inelastic energy demand: For the electricity and oil tax regression, the coefficients of the interaction term between lobby representatives and fuel demand elasticities are negative and (weakly and 
highly) significant. Since the value of the interaction term increases when lobby power increases and the absolute elasticity values decrease, we find that sectors that have high lobbying power and inelastic energy use are taxed at a lower rate. This result is especially interesting when we look at the highly significant negative impact of the price elasticity of oil demand on the tax rate: Although sectors with price-inelastic oil demand ceteris paribus face higher tax rates, these sectors receive lower fuel oil taxes when featuring a great number of lobby representatives.

The straightforward interpretation is that sectors are able to achieve lower tax rates as long as they are represented by a powerful lobby which can argue with inelastic energy use. Seeking for strong political representation is worthwhile for sectors that are relatively dependent on energy use - a more powerful lobby amplifies the concerns of energy dependent industries vis-à-vis the policymakers.

In the following regression specifications, we will again concentrate on the variable $L O B B Y$ rather than the interaction term in order to combine the $L O B B Y$ regressor with alternative policy-relevant variables and analyze the respective interactions.

\subsection{The role of market concentration}

The following regression specification extends the basic specification in order to analyze the implications of market concentration for environmental tax differentiation across sectors. More concentrated industries should have a higher degree of interest organization (Olson 1965) and should therefore be more able to put forward their political positions. Estimating a specification in which the variable CONC is added to the basic specification does, however, not show a significant effect of the degree of market concentration on energy tax rates.

A higher concentration should also enable sectors to better bring forward their arguments against environmental taxation since the tax incidence is concentrated on a smaller number of businesses. In the political debate, one argument of firms opposing an environmental tax reform is the threat of potential production losses and their economic consequences which most commonly means layoffs of workers. The following regression specification extends specification 1 by market concentration as well as an interaction term between concentration and employment in order to investigate how the effect of market concentration on tax rates depends on the sectoral labor force as a politically relevant factor. Estimation results of the regression specification (specification 3) can be found in Table 8 . 
Table 8: Parameter estimation of the extended regression specification including market concentration and interaction term between concentration and employment (specification 3)

\begin{tabular}{|c|c|c|c|}
\hline $\mathrm{N}_{\begin{array}{c}\text { Explanatory } \\
\text { variables }\end{array}}^{\begin{array}{c}\text { Dependent } \\
\text { variable }\end{array}}$ & $E L E \_T A X$ & GAS_TAX & OIL_TAX \\
\hline $\log E L E \_I N T$ & $\begin{array}{c}-0.606 * * \\
(-2.54)\end{array}$ & & \\
\hline logGAS_INT & & $\begin{array}{c}-0.388 * \\
(-1.74) \\
\end{array}$ & \\
\hline $\operatorname{logOIL\_ INT}$ & & & $\begin{array}{l}-0.040 \\
(-0.32)\end{array}$ \\
\hline EMPL & $\begin{array}{c}0.459 * * * \\
(4.00)\end{array}$ & $\begin{array}{c}0.703 * * * \\
(3.46)\end{array}$ & $\begin{array}{c}0.925 * * * \\
(4.25)\end{array}$ \\
\hline$E \_E L E$ & $\begin{array}{l}-0.020 \\
(-0.19)\end{array}$ & & \\
\hline$E_{-} G A S$ & & $\begin{array}{l}-0.008 \\
(-0.05) \\
\end{array}$ & \\
\hline$E_{-} O I L$ & & & $\begin{array}{c}-0.266 * * \\
(-2.12)\end{array}$ \\
\hline LOBBY & $\begin{array}{c}-0.245 * * \\
(-2.45) \\
\end{array}$ & $\begin{array}{c}-0.413 * * * \\
(-4.23)\end{array}$ & $\begin{array}{c}-0.568 * * * \\
(-4.89)\end{array}$ \\
\hline CONC & $\begin{array}{l}-0.038 \\
(-0.34) \\
\end{array}$ & $\begin{array}{l}.0896 \\
(0.36) \\
\end{array}$ & $\begin{array}{l}-0.057 \\
(-0.29) \\
\end{array}$ \\
\hline CONC_EMPL & $\begin{array}{c}-0.203 * * * \\
(-2.83)\end{array}$ & $\begin{array}{c}-0.416 * * * \\
(-3.10)\end{array}$ & $\begin{array}{c}-0.437 * * * \\
(-3.09)\end{array}$ \\
\hline Constant & $\begin{array}{l}2.505 \\
(1.26)\end{array}$ & $\begin{array}{c}0.443^{*} \\
(1.85)\end{array}$ & $\begin{array}{c}10.385 * * * \\
(4.30)\end{array}$ \\
\hline Goodness of fit & $\mathrm{R}^{2}=0.77$ & $\mathrm{R}^{2}=0.61$ & $\mathrm{R}^{2}=0.56$ \\
\hline
\end{tabular}

Z-statistics in parentheses. $*(* *, * * *)$ means the null hypothesis that the respective parameter is zero can be rejected at the $10 \%(5 \%, 1 \%)$ level of significance (according to the corresponding two-tailed test).

The results confirm the effects of energy intensities and demand elasticities on tax rates as derived in the previous regression specifications. Furthermore, the coefficients of employment (lobby employees) are now highly significant in all three (two of the three) regression equations. While coefficients of the variable CONC are again insignificant, the highly significant negative effect of CONC_EMPL on all three energy tax rates suggests that more concentrated sectors which at the same time employ a larger labor force are able to enforce lower effective tax rates, thereby reducing their specific tax incidence.

Our findings regarding the role of market concentration point to an interesting effect of interest group organization: A higher concentration of sectors only leads to political influence if linked to policy-relevant arguments - here: potential layoffs of workers.

\subsection{The role of international competition}

In the following specification we introduce sector-specific elasticities of substitution between domestic goods and competing imports (so-called Armington elasticities) as additional explanatory variable in order to investigate the impact of international trade exposure on environmental tax differentiation. Unilateral environmental (energy) taxation increases the price of domestic energy-intensive goods, which leads to decline in domestic production as untaxed competing imports become relatively cheaper. The higher the Armington 
elasticities are, the stronger is - ceteris paribus - this substitution effect. Thus, Armington elasticities may also serve as an indirect measure for the relocation of domestic production facilities abroad. In policy practice, relocation is a wide-spread argument of energy- and trade-intensive industries to claim exemption from unilateral environmental taxation (Böhringer and Rutherford 1997).

In order to analyze the implications of international exposure for Germany's environmental tax design, we extend the previous regression specification (specification 3) by sectoral Armington elasticities. The estimation results do, however, not provide a significant effect of the variable $E \_A R M$. We therefore can not argue based on the current data set that sectoral exposure to international trade flows is on its own a significant determinant of environmental taxation. Moreover, the lobby power coefficients are no longer significant in this specification. At second glance, however, these results may emerge due to technical reasons: We observe a strong positive correlation between the explanatory variables LOBBY and E_ARM (see Table 9): Sectors that are more exposed to international trade are represented by a more powerful industrial association. In comparison, other regressors involved in interaction terms by far do not exhibit such strong intercorrelations. As a consequence, we observe again a problem of multicollinearity which may explain the mentioned insignificant coefficient estimates.

Table 9: Correlation coefficients between interacting variables

\begin{tabular}{|c|c|c|c|c|c|}
\hline & EMPL & $E_{-} E L E$ & $E_{-} G A S$ & $E_{-}$OIL & E_ARM \\
\hline CONC & -0.282 & & & & \\
\hline LOBBY & & -0.050 & -0.062 & -0.140 & 0.721 \\
\hline
\end{tabular}

In order to assess if international trade exposure becomes relevant for the environmental tax design in the context of lobbying activity, the following regression specification adds to the above specification an interaction effect between lobby power and the sectoral Armington elasticity. The problem of multicollinearity is considered by dropping the intercorrelated explanatory variables $L O B B Y$ and $E_{-} A R M$, which are then substituted by the corresponding interaction term (yielding specification 4). ${ }^{17}$ The estimation results are in line with previous findings regarding the effects of energy intensities and employment on the respective tax rates, although here significances are lower (see Table 10). Our regressions now indicate a highly significant negative impact of LOBBY_EARM on all three tax rates: Industries that are trade exposed (i.e. exhibit higher Armington elasticities) and at the same time have strong lobby power are taxed at a lower rate. These results emphasize the politicaleconomy role of international competitiveness in environmental tax differentiation and are consistent with the

\footnotetext{
${ }^{17}$ To assure that the goodness of fit has not significantly worsened through the exclusion of two explanatory variables (being replaced by one interaction term) we employ the F-test of the difference of $\mathrm{R}^{2}$ between the original model and model 3. For the electricity, gas and oil tax regression we find an insignificant $\mathrm{F}$ statistic of $-0.51,1.44$ and 1.51, respectively, with 1 and 21 degrees of freedom. The replacement of $L O B B Y$ and $E \_A R M$ by the interaction term therefore has not significantly downgraded the goodness of fit.
} 
conclusion of specification 3: Although trade exposure stand-alone is not considered in the tax design, it becomes relevant when lobby groups put it on the political agenda. ${ }^{18}$

Table 10: Parameter estimation of the extended regression specification including interaction term between lobby power and Armington elasticity (specification 4)

\begin{tabular}{|c|c|c|c|}
\hline Explanatory & $E L E \_T A X$ & GAS_TAX & OIL_TAX \\
\hline $\log E L E \_I N T$ & $\begin{array}{c}-0.595 * * * \\
(-3.06)\end{array}$ & & \\
\hline $\log G A S \_I N T$ & & $\begin{array}{l}-0.445 \\
(-1.66)\end{array}$ & \\
\hline logOIL_INT & & & $\begin{array}{l}-0.106 \\
(-0.55)\end{array}$ \\
\hline EMPL & $\begin{array}{c}0.368 * * * \\
(3.59)\end{array}$ & $\begin{array}{c}0.554 * * \\
(2.54)\end{array}$ & $\begin{array}{c}0.781 * * * \\
(3.77)\end{array}$ \\
\hline$E \_E L E$ & $\begin{array}{l}-0.064 \\
(-0.65)\end{array}$ & & \\
\hline E_GAS & & $\begin{array}{l}0.033 \\
(0.17) \\
\end{array}$ & \\
\hline E_OIL & & & $\begin{array}{l}-0.241 \\
(-1.70)\end{array}$ \\
\hline CONC & $\begin{array}{l}-0.112 \\
(-0.90)\end{array}$ & $\begin{array}{l}0.089 \\
(0.29)\end{array}$ & $\begin{array}{l}-0.115 \\
(-0.45)\end{array}$ \\
\hline CONC_EMPL & $\begin{array}{l}0.062 \\
(0.48)\end{array}$ & $\begin{array}{l}-0.135 \\
(-0.78)\end{array}$ & $\begin{array}{l}-0.194 \\
(-1.03)\end{array}$ \\
\hline LOBBY_EARM & $\begin{array}{c}-0.264 * * * \\
(-4.13)\end{array}$ & $\begin{array}{c}-0.378 * * * \\
(-3.43)\end{array}$ & $\begin{array}{c}-0.532 * * * \\
(-4.23)\end{array}$ \\
\hline Constant & $\begin{array}{l}2.918 \\
(1.60)\end{array}$ & $\begin{array}{l}0.380 \\
(1.38)\end{array}$ & $\begin{array}{c}10.389 * * * \\
(3.89)\end{array}$ \\
\hline Goodness of fit & $\mathrm{R}^{2}=0.81$ & $\mathrm{R}^{2}=0.63$ & $\mathrm{R}^{2}=0.54$ \\
\hline
\end{tabular}

Z-statistics in parentheses. * (**,***) means the null hypothesis that the respective parameter is zero can be rejected at the $10 \%(5 \%, 1 \%)$ level of significance (according to the corresponding two-tailed test).

\section{Conclusion}

This paper analyzed the differentiation of green taxes from a political-economy perspective. Using both a theoretical model and empirical analysis, we studied a revenue-neutral tax reform which links the introduction of ecological taxes with reductions of labor costs.

While previous studies have found only a limited rationale of differentiated taxes based on efficiency grounds, our model predicts substantial effects of lobbying in particular for sectors with highly inelastic energy use: On efficiency grounds, such sectors would be assigned high taxes as they are less distortionary than those in other

\footnotetext{
${ }^{18}$ Note that this is in line with findings in the literature (i.e. Böhringer and Rutherford 2002) that pure efficiency arguments can hardly justify a strong differentiation of taxes. Our analysis indicates that it is indeed political pressure which is a significant driving force of tax differentiation.
} 
sectors. The resulting high costs from taxation, however, lead to high lobbying incentives which in turn can translate into substantially reduced taxes. We used data on the German Ecological Tax Reform to put our predictions to a test.

The regression analysis showed that environmental tax differentiation is consistent with political-economy reasoning. Both economic characteristics of industries and political interests determine the design of the tax scheme. The reform clearly discriminated in favor of energy-intensive industries by integrating a number of special regulations. Consistent with our model, the central finding of the regression analysis is that for all energy tax components, industries represented by more powerful associations (in terms of the number of lobby representatives) are better able to communicate their interests and enforce lower tax rates.

We found evidence that the effectiveness of interest groups depends not only on the number lobby representatives, but also on market concentration and energy demand elasticities. In particular, lobby activity is more successful if the interest groups can use convincing arguments based on energy dependence and potential losses in labor force, as well as international competitition. Those arguments alone, however, do generally not induce a large differentiation of taxes.

Our empirical analysis indicates that the tax reform discriminated in favor of energy-intensive industries while sectors with high employment levels were taxed more heavily. Regarding their net burden, such labor-intensive sectors benefit from the reform due to reimbursements. Both our model and the empirical analysis therefore indicate one major benefit from using a revenue-neutral reform: although lobbying activities are generally targeted at lower individual tax rates and thereby lead to tax differentiation, sectors benefit from the higher taxes of other sectors and therefore have incentives to counter attempts of those to water down the tax rates. 
AIDT, T.S. (1998): "Political internalization of economic externalities and environmental policy", Journal of Public Economics 69, 1-16.

AIDT, T.S. (1997): “On the political economy of green tax reforms”, University of Aarhus, Department of Economics, Working paper 1997, 20.

ANDERSON, K. (1992): “The Standard Welfare Economics of Policies Affecting Trade and the Environment”, in K. ANDERSON and R. BLACKHURST (eds.): The Greening of World Trade, Hemel Hempstead.

BABIKER, M., BAUTISTA, M., JACOBY, H. AND J. REILLY (2000): "Effects of Differentiating Climate Policy by Sector: A U.S. Example”, MIT Joint Program on the Science and Policy of Global Change Publications, Report 61.

BACH, S., KOHLHAAS, M., C., MEYER, B., PRAETORIUS, B. and H. WELSCH (2003): „Auswirkungen und Perspektiven der Ökologischen Steuerreform in Deutschland : eine modellgestützte Analyse“, Perspektiven der Wirtschaftspolitik 4 (2), 223-238.

BACH, S., BORK, C, KOHLHAAS, M., LUTZ, C., MEYER, B., PRAETORIUS, B. and H. WELSCH (2001): Die ökologische Steuerreform in Deutschland: eine modellgestützte Analyse ihrer Wirkungen auf Wirtschaft und Umwelt. Heidelberg, Physica.

BERNHEIM, B.D. and M.D. WHINSTON (1986): "Menu auctions, resource allocation, and economic influence“, The quarterly journal of economics 101 (1), 1-31.

BÖHRINGER, C. and T.F. RUTHERFORD (1997): "Carbon taxes with exemptions in an open economy: a general equilibrium analysis of the German tax initiative“, Journal of Environmental Economics and Management 32 (2), 189-203.

BÖHRINGER, C. and T.F. RUTHERFORD (2002): "In search of a rationale for differentiated environmental taxes”. ZEW Discussion Paper 02-30, Centre for European Economic Research, Mannheim, Germany.

BÖHRINGER, C. and R. SCHWAGER (2003): „Die Ökologische Steuerreform in Deutschland: ein umweltpolitisches Feigenblatt“, Perspektiven der Wirtschaftspolitik 4 (2), 211-222.

BÖHRINGER, C. and T.F. RUTHERFORD (2002): "In search of a rationale for differentiated environmental taxes”. ZEW Discussion Paper 02-30, Centre for European Economic Research, Mannheim, Germany.

BOVENBERG, A.L. and F. van der PLOEG (1996): „Optimal taxation, public goods and environmental policy with involuntary unemployment“, Journal of public economics 62 (1/2), 59-83.

CAPROS, P., GEORGAKOPOUlOS, P., VAN REGEMORTER, D., PROOST, S., SCHMIDT, T.F.N., KOSCHEL, H., CONRAD, K., and E.L. VOUYOUKAS (1999): "Climate Technologies Strategies, The Macroeconomic Cost and Benefit of Reducing Greenhouse Gas Emissions in the European Union”, ZEW Economic Studies 4, Mannheim.

COUGHLIN, P.J. (1992): Probabilistic Voting Theory. Cambridge, Cambridge University Press. 
DIJKSTRA, B.R. (1998): „A two-stage rent-seeking contest for instrument choice and revenue division, applied to environmental policy“, European journal of political economy 14 (2), 281-301.

FREDERIKSSON, P.G. (1997): “The political economy of pollution taxes in a small open economy”, Journal of Environmental Economics and Management 33, 44-58.

GERMAN MONOPOLIES COMMISSION (2004): Fifteenth main report of the German Monopolies Commission 2002/2003.

GERMAN MONOPOLIES COMMISSION (2004a): Annexes to the fifteenth main report of the German Monopolies Commission 2002/2003.

GROSSMAN, G.M. and E. HELPMAN (1994): "Protection for sale”, American Economic Review 84 (4), $833-$ 850.

GROSSMAN, G.M. and E. HELPMAN (2001): Special interest politics. Cambridge, MIT Press.

HOEL, M. (1996): “Should a carbon tax be differentiated across sectors?”, Journal of Public Economics 59, 1732.

KALLBEKKEN, S. (2004): "The cost of sectoral differentiation of climate policy: The case of the EU emissions trading scheme”, Paper presented at the European Association of Environmental and Resource Economists (EAERE) Annual Conference 2004, Budapest.

KRUTILLA, K. (1991): “Environmental regulation in an open economy”, Journal of Environmental Economics and Management 20, 127-142.

NAEDVAL, E. and R.J. BRAZEE (2000): “A guide to extracting information from environmental pressure groups”, Environmental and Resource Economics 16 (1), 105-119.

OATES, W.E. and P.R. PORTNEY (2003): "The Political Economy of Environmental Policy” in MÄLER, K.G. (ed.): Handbook of environmental economics, Vol. 1 (2003). Amsterdam, Elsevier, 325-354.

OECD (2001): Environmentally related taxes in OECD countries: issues and strategies, Paris.

OLSON, M. (1965): The logic of collective action. Cambridge, Harvard University Press.

POTTERS, J. and F. VAN WINDEN (1992): “Lobbying and asymmetric information“, Public Choice 74, 269292.

RAUSCHER, M. (1994): “On Ecological Dumping”, Oxford Economic Papers 46 (4), 822-840.

RICHTER, W.F. and K. SCHNEIDER (2003): "Energy taxation: reasons for discriminating in favor of the production sector”, European Economic Review 47, 461-476.

TULLOCK, G. (1980): “Efficient rent seeking” in BUCHANAN, J.M., TOLLISON, R.D. and G. TULLOCK (eds.): Toward a theory of the rent-seeking society. Texas, A\&M University Press, 97-112.

WELSCH, H. (2004): “Sectoral Armington Elasticities in the European Community: Estimates and an Application to Environmental Fiscal Reform”, Working Paper, Department of Economics, University of Oldenburg. 
Table 1: Listing of German manufacturing sectors (Input-output classification)

\begin{tabular}{|c|c|}
\hline Sector No. IOT 1993 & Name of sector \\
\hline 1 & Agricultural products \\
\hline 2 & Forestry \& fishery products \\
\hline 3 & Electric power \& steam \& warm water \\
\hline 4 & Gas \\
\hline 5 & Water (distribution) \\
\hline 6 & Coal \& coal products \\
\hline 7 & Minery products (without coal \& gas \& petroleum) \\
\hline 8 & Crude oil \& natural gas \\
\hline 9 & Chemical products \& nuclear fuels \\
\hline 10 & Oil products \\
\hline 11 & Plastics \\
\hline 12 & Rubber \\
\hline 13 & Stone \& lime \& cement \\
\hline 14 & Ceramic \\
\hline 15 & Glass \\
\hline 16 & Iron \& steel \\
\hline 17 & Non-ferrous metals \\
\hline 18 & Casting products \\
\hline 19 & Rolling products \\
\hline 20 & Production of steel etc \\
\hline 21 & Mechanical engineering \\
\hline 22 & Office machines \\
\hline 23 & Motor vehicles \\
\hline 24 & Shipbuilding \\
\hline 25 & Aerospace equipment \\
\hline 26 & Electrical engineering \\
\hline 27 & Engineers' small tools \\
\hline 28 & Metal and steel goods \\
\hline 29 & Music instruments \& toys etc \\
\hline 30 & Timber \\
\hline 31 & Furniture \\
\hline 32 & Paper \& pulp \& board \\
\hline 33 & Paper \& board products \\
\hline 34 & Printing and publishing \\
\hline 35 & Leathers \& footwear \\
\hline 36 & Textiles \\
\hline 37 & Clothing \\
\hline 38 & Food products \\
\hline 39 & Beverages \\
\hline 40 & Tobacco products \\
\hline 41 & Building \& construction \\
\hline 42 & Recovery \& repair \\
\hline
\end{tabular}


Table 2: Description of regression variables

\begin{tabular}{|c|c|}
\hline Variable & Description \\
\hline$E L E \_T A X$ & Electricity tax rate $(€ / \mathrm{MWh})$ \\
\hline GAS_TAX & Gas tax rate (€/MWh) \\
\hline OIL_TAX & Fuel oil tax rate $(€ / 10001)$ \\
\hline NETB & Net burden $(\mathrm{m} €)$ \\
\hline ELE_INT & Electricity intensity (GWh / €) \\
\hline GAS_INT & Gas intensity $(\mathrm{GWh} / €)$ \\
\hline OIL_INT & Fuel oil intensity $(10001 / €)$ \\
\hline EN_INT & Total energy intensity (GWh / €) \\
\hline logELE_INT & Natural logarithm of ELE_INT \\
\hline $\log G A S \_I N T$ & Natural logarithm of GAS_INT \\
\hline $\log O I L \_I N T$ & Natural logarithm of $O I L \_I N T$ \\
\hline $\log E N \_I N T$ & Natural logarithm of EN_INT \\
\hline$E M P L$ & Employment (1000) \\
\hline$E \_E L E$ & Price elasticity of electricity demand (absolute value) \\
\hline E_GAS & Price elasticity of gas demand (absolute value) \\
\hline E_OIL & Price elasticity of fuel oil demand (absolute value) \\
\hline E_FUEL & Price elasticity of total fuel demand (absolute value) \\
\hline$L O B B Y$ & Total number of lobby representatives per sector \\
\hline$L O B B Y \_E E L E$ & Interaction term (LOBBY / E_ELE) \\
\hline LOBBY_EGAS & Interaction term (LOBBY / E_GAS) \\
\hline LOBBY_EOIL & Interaction term (LOBBY / E_OIL) \\
\hline CONC & Herfindahl-Hirschman Index HHI (x 1000) \\
\hline CONC_EMPL & Interaction term $(C O N C * E M P L)$ \\
\hline$E \_A R M$ & Armington Elasticity between imports and domestic goods \\
\hline LOBBY_EARM & Interaction term $\left(L O B B Y * E \_A R M\right)$ \\
\hline
\end{tabular}

Table 3: Summary statistics for regression variables

\begin{tabular}{|c|c|c|c|c|c|}
\hline VARIABLE & OBSERV. & MEAN & STD. DEV. & MIN. & MAX. \\
\hline ELE_TAX & 42 & 5.57 & 3.83 & 1.31 & 19.91 \\
\hline GAS_TAX & 42 & 0.61 & 0.31 & 0.32 & 1.61 \\
\hline OIL_TAX & 42 & 7.73 & 3.82 & 4.05 & 20.19 \\
\hline NETB & 42 & -30.36 & 68.49 & -278.16 & 68.97 \\
\hline ELE_INT & 42 & 0.29 & 0.34 & 0.00 & 1.63 \\
\hline GAS_INT & 42 & 0.47 & 0.74 & 0.00 & 3.23 \\
\hline OIL_INT & 42 & 5.16 & 5.11 & 0.08 & 29.29 \\
\hline EN_INT & 42 & 0.82 & 0.95 & 0.03 & 4.27 \\
\hline EMPL & 42 & 294.36 & 380.97 & 9.00 & 1709.00 \\
\hline$E \_E L E$ & 42 & 0.26 & 0.09 & 0.19 & 0.39 \\
\hline$E \_G A S$ & 42 & 0.62 & 0.15 & 0.10 & 0.82 \\
\hline$E \_O I L$ & 42 & 0.58 & 0.18 & 0.10 & 0.89 \\
\hline$E \_F U E L$ & 42 & 0.46 & 0.13 & 0.16 & 0.69 \\
\hline LOBBY & 42 & 49.50 & 67.09 & 0.00 & 350.00 \\
\hline CONC & 36 & 62.87 & 84.63 & 2.80 & 357.65 \\
\hline$E \_A R M$ & 35 & 0.69 & 0.48 & 0.08 & 2.36 \\
\hline
\end{tabular}


Table 4: German manufacturing sectors and respective industrial associations

\begin{tabular}{|c|c|c|}
\hline Sector No. & Name of sector & Industrial associations \\
\hline 1 & Agricultural products & German Farmers Association (DBV) \\
\hline 2 & Forestry \& fishery products & $\begin{array}{l}\text { German Forestry Council (DFWR) } \\
\text { German Fishery Association (DFV) }\end{array}$ \\
\hline 3 & Electric power \& steam \& warm water & German Electricity Association (VDEW) \\
\hline 4 & Gas & Association of the German Gas and Water Industries (BGW) \\
\hline 5 & Water (distribution) & Association of the German Gas and Water Industries (BGW) \\
\hline 6 & Coal \& coal products & $\begin{array}{l}\text { German Mining Association (WVB) } \\
\text { German Hard Coal Association (GVST) } \\
\text { German Lignite Industry Association (DEBRIV) }\end{array}$ \\
\hline 7 & Minery products (without coal \& gas \& petroleum) & German Mining Association (WVB) \\
\hline 8 & Crude oil \& natural gas & Association of the German Oil and Gas Producers (WEG) \\
\hline 9 & Chemical products \& nuclear fuels & Association of the German Chemical Industry (VCI) \\
\hline 10 & Oil products & Association of the German Petroleum Industry (MWV) \\
\hline 11 & Plastics & $\begin{array}{l}\text { Association of the German Plastics Processing Industry (GKV) } \\
\text { Federation of German Woodworking and Furniture Industries (HDH) } \\
\text { Federation of German Paper, Cardboard and Plastics Processing Ind. (HPV) }\end{array}$ \\
\hline 12 & Rubber & German Rubber Manufacturers’ Association (WDK) \\
\hline 13 & Stone \& lime \& cement & German Building Materials Association (BBS) \\
\hline 14 & Ceramic & German Federation of Fine Ceramic Industry (AKI) \\
\hline 15 & Glass & German Glass Industry Federation (BV Glas) \\
\hline 16 & Iron \& steel & $\begin{array}{l}\text { German Steel Federation (WV Stahl) } \\
\text { German Federation of Steel and Metal Processing (WSM) }\end{array}$ \\
\hline 17 & Non-ferrous metals & $\begin{array}{l}\text { Federation of the German Non-Ferrous Metals Industry (WVM) } \\
\text { Federation of German Steel and Metal Processing (WSM) }\end{array}$ \\
\hline 18 & Casting products & German Foundry Association (DGV) \\
\hline 19 & Rolling products & $\begin{array}{l}\text { Association of German Drawing Mills (STV) } \\
\text { Association of German Cold Rolling Mills (FVK) }\end{array}$ \\
\hline 20 & Production of steel etc & German Structural Steel and Power Engineering Association (SET) \\
\hline
\end{tabular}


Table 4 (continued): German manufacturing sectors and respective industrial associations

\begin{tabular}{|c|c|c|}
\hline Sector No. & Name of sector & Industrial associations \\
\hline 21 & Mechanical engineering & Federation of the German Engineering Industry (VDMA) \\
\hline 22 & Office machines & - \\
\hline 23 & Motor vehicles & Association of the German Automotive Industry (VDA) \\
\hline 24 & Shipbuilding & German Shipbuilding and Ocean Industries Association (VSM) \\
\hline 25 & Aerospace equipment & German Aerospace Industries Association (BDLI) \\
\hline 26 & Electrical engineering & German Electrical and Electronic Manufacturers’ Association (ZVEI) \\
\hline 27 & Engineers' small tools & $\begin{array}{l}\text { German Industrial Association for Optical, Medical and Mechatronical Technologies (SPECTARIS) } \\
\text { Federation of German Jewellery, Watches, Clocks, Silverware and Related Industries }\end{array}$ \\
\hline 28 & Metal and steel goods & - \\
\hline 29 & Music instruments \& toys etc. & $\begin{array}{l}\text { National Association of German Musical Instruments Manufacturers (BDMH) } \\
\text { German Association of the Toy Industry (DVSI) }\end{array}$ \\
\hline 30 & Timber & $\begin{array}{l}\text { Federation of German Woodworking and Furniture Industries (HDH) } \\
\text { Association of the German Sawmill and Wood Industry (VDS) }\end{array}$ \\
\hline 31 & Furniture & Federation of German Woodworking and Furniture Industries (HDH) \\
\hline 32 & Paper \& pulp \& board & German Pulp and Paper Association (VDP) \\
\hline 33 & Paper \& board products & $\begin{array}{l}\text { German Pulp and Paper Association (VDP) } \\
\text { Federation of German Paper, Cardboard and Plastics Processing Industry (HPV) }\end{array}$ \\
\hline 34 & Printing and publishing & German Printing Industry Federation (BVDM) \\
\hline 35 & Leathers \& footwear & $\begin{array}{l}\text { German Leather Federation (VDL) } \\
\text { Federation of the German Shoe Industry (HDS) }\end{array}$ \\
\hline 36 & Textiles & Federation of German Textile and Fashion Industry \\
\hline 37 & Clothing & Federation of the German Clothing Industry (BBI) \\
\hline 38 & Food products & Federation of the German Food and Drink Industries (BVE) \\
\hline 39 & Beverages & Federation of the German Food and Drink Industries (BVE) \\
\hline 40 & Tobacco products & Federation of the German Cigarette Industry (VdC) \\
\hline 41 & Building \& construction & German Construction Industry Federation (HDB) \\
\hline 42 & Recovery \& repair & German Construction Industry Federation (HDB) \\
\hline
\end{tabular}

